\title{
POLISH FDI IN UKRAINE: ANALYZING LOCATION FACTORS, INVESTMENT TRENDS AND FIRM-LEVEL ACTIVITY
}

In the context of a theoretical framework and the literature review summarizing the empirical findings, the authors analyze Ukraine's location advantages and disadvantages visà-vis FDI and present the major macro and meso-economic trends in Poland's FDI flows to and stock in Ukraine. At the micro level, the paper presents the results of an analysis of a sample of 18 companies from the Warsaw Stock Exchange that have invested in Ukraine. One of the main findings reveals a discrepancy between the modest value of Polish FDI in Ukraine and the relatively large number of Polish firms' subsidiaries and affiliates operating in the country. Analysis of the sample of units controlled by Polish parent companies in Ukraine allows for reaching conclusions about their assets, FDI motives and modes, types of FDI undertaken, and sales results. The authors wrap up the paper by drawing both policy implications for Ukraine and Poland, and the managerial implications for Polish direct investors in Ukraine.

Keywords: Outward foreign direct investment (FDI); Poland; FDI location factors; Ukraine

DOI: $10.15611 /$ aoe.2015.1.08

\section{INTRODUCTION}

With a population of over 46 million, a strong though somewhat erratic economic growth, averaging 5\% over the period of 2001-2011 (according to World Bank data), and a recent geopolitical re-orientation towards Europe, Ukraine is potentially an attractive market for FDI. ${ }^{1}$ And yet, for its Western Slavic neighbour, Poland, Ukraine is not among the top destinations for outward FDI, trailing far behind such small countries as Luxembourg and Cyprus (Zimny, 2013). At the same time, however, Ukraine hosts the second

\footnotetext{
* Tischner European University, Cracow

** Rzeszów University of Information Technology and Management

${ }^{1}$ Although some updates were made in 2014, this article was prepared prior to the current political crisis and military conflict in Eastern Ukraine. Therefore the authors have taken no account of the current situation in Ukraine.
} 
largest number of Polish companies' foreign subsidiaries. Clearly, there is a discrepancy between the level of interest and the activity of Polish companies in Ukraine, and the amount of the capital they commit to this host country. Intrigued by this discrepancy, we set out to investigate Ukraine's location advantages and disadvantages vis-à-vis FDI, the level and changes of its inward FDI, the evolution of Poland's outward FDI destined for Ukraine, and Polish investors' activity and performance in Ukraine.

Intended to be the first stage in a multi-stage research project, this paper aims at revealing the major trends in Poland's overall FDI in Ukraine, its sectoral distribution, as well as the patterns of behaviour of a sample of companies that have invested in Ukraine. In turn, the findings of this exploratory study are expected to guide the subsequent stages of the current research project.

The paper is structured as follows. After laying the theoretical foundations and reviewing the relevant literature, we consider Ukraine's FDI location factors, analyzing and assessing both the advantages and disadvantages of Ukraine as a destination for FDI in general, and for Polish FDI in particular. The subsequent section is devoted to an analysis of the macro and meso-economic trends in Poland's flows to and stock in Ukraine, and an analysis of the general patterns in the number and geographic distribution of Polish enterprises' subsidiaries and affiliates abroad. This is followed by a presentation and discussion of the results of an analysis of a sample of 18 companies drawn from those listed on the Warsaw Stock Exchange that have invested in Ukraine. Among other things, we look at the sample companies' Ukrainian subsidiary characteristics, modes of entry, type of investment undertaken, and sales performance. The paper is wrapped up with a concluding section, summarizing the main findings and drawing appropriate conclusions, as well as outlining policy and managerial recommendations.

\section{FDI AND LOCATION FACTORS - THEORETICAL FOUNDATIONS AND EMPIRICAL FINDINGS}

FDI theory states that the location decisions of firms investing abroad are determined by the relative location advantages of particular countries for certain activities. Locations abundant in particular resources will attract FDI that makes intensive use of these resources (Dunning 1993). At the same time, location (L) advantages represent one set of advantages determining FDI, alongside firm ownership (O) advantages and internalization (I) 
advantages, as embedded in Dunning's OLI Paradigm (Dunning, 2001). Since the OLI Paradigm incorporates and combines a number of FDI theories, it is considered the most holistic explanation of FDI activity.

Although one can look at each pillar of the OLI model separately, there are important interdependences between them. Thus, location decisions are not only dependent on the countries location advantages and disadvantages, but also on the firm's ownership (O) and internalization (I) advantages. As Dunning (1988) notes: "While, in the eclectic paradigm, the advantages and disadvantages of particular locations are treated separately form the ownership advantages of particular enterprises, and while the market for these advantages are internalized; the decision on where to site a mine, factory or office is not independent of the ownership of these assets nor of the route by which or their rights are transacted" (p. 4).

Several factors have been identified in the literature as important determinants of FDI location. They include: market size and growth, political stability, investment climate, trade barriers, factor endowments and costs, agglomeration effects, cultural and physical distance, government incentives, and institutional infrastructure. Market size and growth are probably the most frequently studied host-country determinants of FDI, very often measured by the GDP proxy. They are sometimes referred to as marketing or aggregate variables (Faeth, 2009).

The studies of Busse and Hefeker (2007), and Brouthers et al. (2009), indicate that government stability, internal and external conflict, corruption and ethnic tensions, law and order, democratic accountability of government, and quality of bureaucracy are highly significant determinants of foreign investment inflows. In the same vein, Bloningen (2005) considers the quality of institutions to be an important determinant of FDI activity, particularly for less-developed countries, and points out that such problems as poor legal protection of assets, poor quality of institutions necessary for wellfunctioning markets and corruption increase the cost of doing business and diminish FDI activity. Dunning (2005), and Dunning and Lundan (2008) have also recognized the importance of institutional infrastructure (II) determining FDI location decisions, particularly with respect to FDI inflows to transition economies.

Faeth's (2009) literature review indicates that policy variables, including host government incentives, are potentially important variables determining the location of FDI. However, it is noted by this author that "Tax policy cannot compensate for a negative investment climate, though fiscal incentives can promote investment in a favourable investment climate" (p. 187). 
Since its incorporation into the Uppsala Model (Johanson and Vahlne, 1977), the construct "cultural or psychological distance" has been given a lot of consideration in FDI studies. Examples of studies of FDI determinants incorporating cultural distance are those of Chapman et al. (2008), Buckley et al. (2007), Bevan and Estrin (2004), Shenkar (2001), Brouthers and Brouthers (2001), and Loree and Guisinger (1995). Chapman et al. argue that " $(\ldots)$ cultural distance should be considered as relative and not absolute, and that it should be treated on a bilateral basis" (pp. 217-218).

According to the UNTCAD's World Investment Prospect Survey (2009), conducted among foreign investors, market-potential and market-access related factors are the most important determinants for a location's attractiveness for business services. In particular, size, growth of local markets and access to international/regional markets, and availability of suppliers and partners are regarded as the main location considerations. Further on in importance are a stable and business-friendly environment and availability of skilled labour and talent. It is interesting to note that availability of skilled labour is a more important location factor than labour costs, also fairly important was quality of infrastructure. The most striking result from this survey is the very minor importance of government effectiveness and incentive, and access to finance as determinants of FDI location.

Combining theoretical considerations with empirical results, one can point to the particular importance of such FDI location factors as market size, growth and access, availability and cost of skilled labour, stability of business/investment environment, and quality of infrastructure and government. It should be, however, recognized that the importance of these factors changes depending on the destination countries. For example, in developing and transition countries, government stability, quality of institutions, including the legal protection of assets and corruption, may be significant factors in the assessment of a country's investment attractiveness.

\section{FDI IN UKRAINE: LITERATURE REVIEW}

FDI inflows into Ukraine have attracted a limited amount of research. This is in contrast to the substantial amount of studies dedicated to inward FDI in Central and Eastern European members of the EU. The very few studies focused on FDI in Ukraine deal mostly with the spillover effects of FDI, the role of FDI as a catalyst of economic development, government policy towards FDI, and the effects of the political situation and corruption 
on FDI inflows. A number of studies focus on Ukraine's location advantages and disadvantages (these will be covered in greater detail in the subsequent section).

Lutz and Talavera's (2003) study of FDI spillover effects in Ukraine considered both the negative and positive effects. The negative effects might occur in the form of increased monopoly power of multinational corporations (MNC) that might have a strong incentive to acquire and eliminate Ukrainian competitors. As for the positive effects, these authors find FDI presence in Ukraine to be beneficial to both labour productivity and exports. This positive influence is also found, although to a small degree, among firms that did not receive FDI, which attests to the presence of FDI spillovers.

FDI in Eastern Europe is widely considered as an important catalyst of economic development, especially in the case of export-oriented FDI. However, it is often emphasized that the strength of the positive impact depends on the capacity of the domestic firms to absorb FDI and the host country government to facilitate its positive impacts through an appropriate institutional infrastructure. Tytell and Yudaeva's (2005) study of four transition countries, including Ukraine, indicates that knowledge spillovers occur mostly in more educated and less corrupt host country environments. These authors also point out that FDI benefits are more likely to materialize once a certain (threshold) level of FDI stock is accumulated. Eastern European governments, therefore, try to develop and introduce policies aimed at attracting FDI and stimulating spillover effects (Tytell and Yudaeva, 2005).

In turn, a study by Kudina and Jakubiak (2008), based on a survey of 120 investors in a group of the CIS countries including Ukraine, indicates that spillovers arising from the cooperation between foreign investors and local firms are weak. This is because non-oil investors in these countries are oriented toward serving local markets and operate as "isolated players", having more links with their parent companies than with local firms, thus securing very few supplies locally. This study also reports a lack of efficiency-seeking investment and points to the volatility of the political and economic environments, as well as the ambiguity of the legal system and corruption as major problems faced by foreign investors in the group of CIS countries.

Research conducted by Crane and Larrabee (2007) for RAND, a U.S. military and intelligence research institution, shows that the environment for foreign trade and investment in Ukraine has been improving relatively 
slowly as the Ukrainian government has found it difficult to liberalize trade and improve investment climate, which is crucial to attracting FDI. Among several critical barriers to FDI, these authors point to corruption playing a major role, as "foreign businesses complain most vociferously about Ukrainian regulatory and legal hurdles designed to elicit bribes" (Crane and Larrabee; 2007, p. 11). Among other barriers are trade barriers, such as the corruption-ridden VAT reimbursement for exporters and import certifying systems. This research also provides insights into the difficulty investors encounter in Ukraine as a result of serious deficiencies in the existing law (e.g. shareholders rights of ownership are not sufficiently protected), and complex, time-consuming and costly approval procedures.

A publication of the Institute of Economic Research and Policy Consulting in Ukraine (2007) shows that despite some legislative barriers, since the beginning of 2005 Ukraine has slowly started to attract a respectable amount of FDI. This investment concentrated more on the services sector (mainly financial intermediation) than on manufacturing. The authors of this publication point out that before 2005 some of the FDI were related to privatization, mainly of several energy generating and chemical enterprises. On the other hand, Mac (2008), points out that the "country's success is attributable to several factors: a maturing private sector (...), the country's relatively inexpensive and well educated workforce, and Ukraine's entry into the WTO on May 16th 2008". Mac also draws attention to regulatory and legal hurdles and corruption, but describes the Ukrainian market as lucrative.

The above view is also central to a report prepared by Kononov (2010) for Vale Columbia Center on Sustainable International Investment (VCC). This author points to such potential advantages of Ukraine as an FDI destination, as a sizeable market, low competitiveness of domestic firms, favourable geographic location, low costs of labour and other inputs, and rich natural resources. According to Kononov, these potential advantages are not being exploited due to FDI impediments created by the legal framework, political risks and corruption.

Similarly to Kononov (2010), Tansil and Eff (2011), recognize Ukraine's FDI potential while admitting modest current levels of FDI inflows. They state: "Ukraine has the second largest population of the former Soviet states, with abundant agricultural resources, an excellent education system and a well-developed industrial base. Nevertheless, Foreign Direct Investment has been scarce" (p. 1). Although FDI has been growing and the economy is relatively stable, politics and government scandals diminish Ukraine's 
attractiveness and increase risks. Tansil and Eff (2011) point to a number of factors that might overcome political instability: well-educated workforce, diverse industrial structure, rich farmlands, productive mines, and its location on the periphery of Europe providing access to European and Central Asian markets. These authors assert that the recent legislative reforms have brought changes and transparency to the economy. The reforms, together with an acceleration of privatization and enhancement of the country's financial sector, should improve Ukraine's investment climate in the future.

One of the major factors attracting investors to Ukraine might be the recent discovery of non-conventional gas reserves (Lijdsman, 2010). However, Lijdsman (2010) predicts most of the foreign investors in this sector are firstly targeting Poland, as it has a better business climate and higher-quality institutional infrastructure. Ernst \& Young's (2011) report on Ukrainian FDI also recognizes increasing interests in the natural gas sector, especially from Russia wanting to maintain its stable relationship with the country. Similarly to the previously cited studies, Ernst \& Young's report shows that "Ukraine's uncertainty regarding its investments climate limits investors' enthusiasm and undermines its true investment potential". Nevertheless, the report conveys an optimistic view regarding the improving investment climate of Ukraine and predicts robust growth in FDI inflows.

Recent positive changes, albeit slowly implemented by the Ukrainian government, create an opportunity to open a new chapter in the country's inward FDI. Polish companies have started investing abroad on a significant scale and they consider Ukraine to be a valuable non-saturated market (Bonikowska et al, 2012). According to Zimny's (2013) study prepared for VCC, Poland has the largest outward FDI among the new EU members, with the bulk of its outward FDI stock located in the EU. A close neighbour of Poland, Ukraine is not a top destination for Polish investors as far as the value of FDI is concerned. However, Ukraine as a host country features prominently when the number of foreign affiliates (FAs), employment in FAs and sales of FAs are taken into account.

\section{UKRAINE'S FDI LOCATION FACTORS}

The purpose of this section is to assess Ukraine's FDI location advantages and disadvantages. This is done in light of the two preceding sections that dealt with the theoretical foundations and empirical results of FDI location studies, and the literature review on FDI developments in Ukraine, respectively. 
As transpired from the literature review in the preceding section, Ukraine certainly has location advantages vis-à-vis foreign investors. Several of these factors were mentioned in that literature review, including: large market potential, low competitiveness of domestic companies, maturing private sector, relatively inexpensive and well-educated workforce, rich natural resources, and a relatively well-developed industrial base. Indeed, Kraszewski et al. (2010) find these and other factors as stimulating direct foreign investments in the Ukrainian market. Other favourable location factors identified by Karaszewski et al. include: good geographic location, good prospects for economic growth, existence of market niches, import substitution initiatives, and high returns on invested capital. Arguably, as a result of these attractions, and in spite of the many impediments to investing in Ukraine discussed below, entities from over 130 countries conducted their businesses in Ukraine in 2013. The value of the capital stock invested in the Ukrainian economy in the form of FDI was USD 54.5 billion as of 01.01.2013 (State Statistics Service of Ukraine, 2013). However, this figure compares unfavourably to Poland's inward FDI stock of over USD 200 billion reported by Zimny (2013).

From the Polish investors' viewpoint, Ukraine, in addition to having the above-listed attractions, has the advantage of being a geographically, politically and culturally close neighbour. Both countries are the second and third largest Slavic nations, and share an over-500-km-long border. The historic and ethnic ties between Poland and Ukraine are described by Burant (1993) as "the ethnic and cultural kinship of the Polish and Ukrainian people." Poland also plays an important role in bringing Ukraine closer to the EU and facilitating the country's EU membership in the future. Moreover, thousands of Ukrainian emigrants who have settled in Poland build additional bridges between the two peoples (according to Iglicka and Gmaj, 2010, every fifth foreigner residing in Poland is Ukrainian). Clearly, the "psychological and cultural distance" between the two country's is relatively small, although one has to keep in mind that Ukraine is a politically and culturally divided country, with its eastern part gravitating toward Russia and its western part looking forward to integration with the EU (Gorzelak and Tucholska, 2008).

At the same time, Ukraine is plagued by political and institutional problems that negatively affect FDI inflows into the country.

Ukraine belongs to the group of transition countries, and since it gained independence in 1991 it has conducted a range of internal reforms as well as made changes in external relations. The changes have so far only slightly 
diminished the risks related to investing and running a business activity in the country. The situation is additionally made worse by the specific economic and investment climate inherited from the socialist system, characterized by corruption and bureaucracy (Herzfeld and Weiss, 2003). It is for these reasons that foreign companies, when investing in Ukraine, must take into account the existence of the considerable political and economic risk.

Before deciding on investing in any country, foreign investors consider the market potential and economic risk that exists or may appear in the host country. A number of agencies specialize in assessing loan attractiveness, economic development, competitiveness, business risk, economic freedom, and corruption in most countries of the world. The rankings for Ukraine from the most prominent of those agencies are provided in Table 1.

Table 1

Ukraine's position in international investment rankings

\begin{tabular}{|c|c|c|c|c|c|}
\hline \multirow{2}{*}{ Institution } & \multirow{2}{*}{ Index } & \multicolumn{4}{|c|}{ Ukraine's position in time } \\
\hline & & 2008 & 2011 & 2012 & 2013 \\
\hline $\begin{array}{l}\text { World } \\
\text { Economic } \\
\text { Forum } \\
\end{array}$ & $\begin{array}{l}\text { Global Competitiveness } \\
\text { Index (a) }\end{array}$ & $\begin{array}{r}72 \\
\text { out of } 131\end{array}$ & $\begin{array}{r}89 \\
\text { out of } 139\end{array}$ & $\begin{array}{r}82 \\
\text { out of } 142\end{array}$ & $\begin{array}{r}73 \\
\text { out of } 144\end{array}$ \\
\hline $\begin{array}{l}\text { Heritage } \\
\text { Foundation }\end{array}$ & \begin{tabular}{|l|} 
Index of Economic \\
Freedom \\
\end{tabular} & $\begin{array}{r}133 \\
\text { out of } 157 \\
\end{array}$ & $\begin{array}{r}164 \\
\text { out of } 179 \\
\end{array}$ & $\begin{array}{r}163 \\
\text { out of } 179 \\
\end{array}$ & $\begin{array}{r}161 \\
\text { out of } 183 \\
\end{array}$ \\
\hline $\begin{array}{l}\text { Transparency } \\
\text { International }\end{array}$ & $\begin{array}{l}\text { Corruption Perception } \\
\text { Index }\end{array}$ & $\begin{array}{r}134 \\
\text { out of } 180 \\
\end{array}$ & $\begin{array}{r}152 \\
\text { out of } 182 \\
\end{array}$ & $\begin{array}{r}144 \\
\text { out of } 174 \\
\end{array}$ & $\begin{array}{r}144 \text { out of } \\
177 \\
\end{array}$ \\
\hline World Bank & Doing Business Index & $\begin{array}{r}144 \\
\text { out of } 179 \\
\end{array}$ & $\begin{array}{r}145 \\
\text { out of } 183\end{array}$ & $\begin{array}{r}152 \\
\text { out of } 183\end{array}$ & $\begin{array}{r}137 \\
\text { out of } 185 \\
\end{array}$ \\
\hline
\end{tabular}

Source: World Economic Forum (2007-2013); Heritage Foundation (2013); Transparency International (2013); World Bank (2013); a) Data for 2007-8, 2010-11, 2011-12, and 2012-13

One of the best known indices in this area is the one presented by the Heritage Foundation, the Index of Economic Freedom, which reflects the state of affairs concerning the most important macroeconomic parameters of 183 countries. The index covers such factors as trade, taxes, government expenditure, investment, and property rights protection. In 2013, Ukraine occupied the $161^{\text {st }}$ place in the Index of Economic Freedom. This is the lowest score among the countries from the European region. That ranking places Ukraine among countries where business is conducted repressively, although it must be noted that the country's position on the Index improved 
by 0.2 points compared to the previous year (from 46.1 points in 2012 to 46.3 points in 2013, respectively). To compare, the first three positions of the said ranking are taken by Hong Kong, Singapore and Australia with 89.3, 88.0, and 82.6 points, respectively. Ukraine's closest neighbours quite outdistance it as regards freedom of conducting business activity, and hence offer a lower risk. For example, Belarus occupies rank 154 (48.0 points), Russia - 139 (51.1 points), Poland - 57 (66.0 points), Turkey - 69 (62.9 points), and the Czech Republic - rank 29 (70.9 points) (The Heritage Foundation, 2013).

Other ranking agencies corroborate Ukraine's high risk associated with running a business. Ukraine's $137^{\text {th }}$ position out of 185 states on the World Bank's "ease of doing business index" (World Bank, 2013) is alarming. Such a low position in a worldwide ranking was brought about by numerous factors. For instance, to start a business in Ukraine one needs to go through an average of 10 procedures, which is almost twice as many as in OECD countries or Eastern European countries (World Bank, 2013). The whole process of starting a business lasts 69 days - which is also more than twice as long as in the above mentioned countries. The situation is similar for construction works or registering property. Procedures for gaining loans and investor protection also pose considerable problems. Several hindrances are faced by entrepreneurs due to serious deficiencies of the fiscal system - for instance high income tax rates and profit transfer tax rates. Foreign investors can take advantage of various concessions when conducting business within the numerous Special Economic Zones and Priority Development Areas, which have been created firstly to attract foreign investors, and secondly to develop (economically) depressed areas by fostering priority businesses. However, it must be stated that the procedure of approving investment projects conducted in those areas is complex and time-consuming. Even the process of exiting a business in Ukraine is much more costly and timeconsuming than in other Eastern European countries.

As was apparent in the literature review section, one of the major factors negatively affecting Ukraine's image among foreign investors is corruption. According to the Corruption Perception Index, Ukraine is the $144^{\text {th }}$ in the ranking, next to Syria and Eritrea. The average level of Ukraine's Corruption Perception Index in 2004-2013 did not exceed 2.5 on a scale where 0 means a totally corrupted state, and 10 means lack of corruption (Transparency International, 2013).

In the Global Competitiveness Index ranking prepared by the World Economic Forum for 2012-2013, Ukraine takes the $73^{\text {rd }}$ position among 144 
states. Although Ukraine's position improved in the most recent ranking compared to the two previous years, it is still slightly worse than it was in 2007-2008. Similarly to other rankings, Ukraine's position on the Global Competitiveness Index is below that of its Eastern European neighbours, except Moldova (Belarus is not ranked).

According to the Embassy of the Republic of Poland in Kiev (2013), Ukraine's basic problems in shaping global competitiveness and favourable investment and trade conditions include:

- elaborate bureaucratic system;

- corruption;

- restrictions on buying real estate and obtaining work permits by foreigners;

- non-transparent, incoherent and changeable Ukrainian laws;

- barriers to trade;

- unfavourable regulations concerning business activity;

- high risk of business activity;

- no incentives and insufficient support for investors from local authorities;

- problems with VAT refunds (these problems concern investors active in Ukraine and exporting their products abroad);

- weak system of justice and problems with pursuing legal rights in courts (administrative bodies not respecting the law or interpreting Ukrainian law in a way that is unfavourable for Polish companies, and lack of uniform application of the binding laws, particularly by local authorities);

- Ukrainian customs questioning and raising the value of imported goods (higher customs taxes) and frequent changes of customs laws;

- slow implementation of changes adjusting Ukrainian legislation to EU and WTO requirements;

- poor infrastructure and few border crossings, which cause long queues at the borders, particularly in the case of freight transport;

- ineffective and corruption-ridden public procurement system.

The above listed rankings and unfavourable institutional factors that have a potential to greatly discourage foreign investors from entering the Ukrainian market, make the attractive location factors discussed earlier less attractive! The next section of this paper provides an empirical investigation of Ukraine as a destination for Polish FDI. 


\section{POLAND'S FDI IN UKRAINE: ANALYSIS OF MACRO AND MESO-TRENDS}

The datasets used in this section are derived from several sources, of which the primary source is the World Bank online database. Additionally, the databases of UNCTAD (on FDI inflows, outflows and stock), the National Bank of Poland (NBP) and the State Statistics Service of Ukraine were used. Availability of data on the Ukrainian economy is very limited this was the primary factor determining why data from the World Bank were widely used. The World Bank's data seem to be the most comprehensive and probably the most accurate public data available on FDI and related statistics.

In spite of the larger population of Ukraine as compared to that of Poland, both GDP and FDI inflows are lower in Ukraine. In Appendix 1 the table shows data for the two variables (GDP and FDI inflows) for the period of 1992-2012. It also shows the ratios of Ukraine's GDP to Poland's and the ratio of FDI net inflows to Ukraine to those of Poland. A comparison of the two ratios can be used as an indicator of the relative attractiveness of FDI location factors of Poland and Ukraine, or - in other words - as an indicator of whether Ukraine is utilizing its economic potential to attract FDI to the same degree as Poland does.

At the beginning of the period under consideration, in 1992 the ratio of Ukraine's GDP to Poland's amounted to 0.80, which means that the GDP of Ukraine represented $80 \%$ of Poland's GDP. The ratio then deteriorated for Ukraine, reaching only 0.18 in 2000. This was the result of Poland's consistent growth and Ukraine's decline in the preceding years. During the 2000s, Ukraine's economy returned to growth, expanding particularly rapidly over the period 2002-2008 (as expressed in current USD). This helped Ukraine to partly close the GDP gap with Poland; in 2012 the GDP ratio for the two countries was 0.36 .

From the point of view of the objectives of this article, a comparison of the two ratios (GDP and FDI inflows) is particularly telling. In the 1990s and the beginning of the 2000s, the GDP ratio was considerably higher than that of FDI inflows. This is a clear indication that Ukraine was poorly utilizing, in comparison to Poland, its economic potential to attract FDI. From 2003 in most of the remaining years, the FDI inflows ratio was higher than that of GDP - Ukraine was clearly catching up to Poland, in relative terms, when it comes to attracting FDI and, surprisingly, in 2012 Ukraine attracted more FDI than Poland did, hence the FDI inflows ratio above 1. It should be 
noted, however, that both countries suffered from the Global Financial Crisis, receiving less FDI in the years 2008-2012 (Poland) and 2009-2012 (Ukraine) than in the pre-crisis years.

As can be observed by examining Table 2, outflows of Polish FDI to Ukraine were growing steadily until 2007; thereafter (perhaps also reflecting the global downturn) they decreased precipitately to assume negative values (USD 382.1 million in 2007 vs. USD -75.6 million in 2008). In 2010 Polish FDI outflows to Ukraine increased to USD 108.5 million, but they dropped again in the subsequent years. Polish FDI stock in Ukraine was also growing - in 1996 it was a mere USD 21 million, while in 2012 it amounted to USD 1091 million, representing an increase of $5195 \%$ over the studied period. Poland's FDI flows to Ukraine as a percentage of total OFDI figures fluctuated widely, sometimes representing more than a quarter of total outflow, and sometimes assuming negative values. On average, however, the percentages were higher between 1996 and 2003 than thereafter. As far as

Table 2

Poland's FDI in Ukraine: Outflows and Outward Stock (1996-2012)

\begin{tabular}{|c|c|c|c|c|c|c|}
\hline Years & $\begin{array}{c}\text { Total FDI } \\
\text { outflows, } \\
\text { USD m }\end{array}$ & $\begin{array}{l}\text { Total outward } \\
\text { FDI stock. } \\
\text { USD m }\end{array}$ & $\begin{array}{l}\text { FDI outflows } \\
\text { to Ukraine, } \\
\text { USD m }\end{array}$ & $\begin{array}{c}\text { \% of } \\
\text { total } \\
\text { outflows }\end{array}$ & $\begin{array}{c}\text { Outward FDI } \\
\text { stock in Ukraine. } \\
\text { USD m }\end{array}$ & $\begin{array}{c}\% \text { of total } \\
\text { outward } \\
\text { FDI stock }\end{array}$ \\
\hline 1996 & 53.0 & 735.2 & 7.0 & 13.2 & 21.0 & 2.9 \\
\hline 1997 & 45.0 & 677.9 & 8.0 & 17.7 & 16.0 & 2.4 \\
\hline 1998 & 317.7 & 1164.7 & 3.0 & 0.9 & 16.0 & 1.4 \\
\hline 1999 & 31.0 & 1024.3 & 3.3 & 10.6 & 15.9 & 1.5 \\
\hline 2000 & 17.0 & 1018.3 & -0.3 & -1.8 & 15.5 & 1.5 \\
\hline 2001 & -88.9 & 1157.0 & 9.5 & -10.7 & 29.0 & 2.5 \\
\hline 2002 & 228.7 & 1456.4 & 22.9 & 10.0 & 47.1 & 3.2 \\
\hline 2003 & 305.0 & 2144.5 & 80.1 & 26.3 & 133.7 & 6.2 \\
\hline 2004 & 900.0 & 3351.0 & 53.4 & 5.9 & 195.5 & 5.8 \\
\hline 2005 & 3436.9 & 6307.6 & 132.2 & 3.8 & 297.3 & 4.7 \\
\hline 2006 & 8883.2 & 14392.4 & 187.7 & 2.1 & 495.0 & 3.4 \\
\hline 2007 & 5404.7 & 21317.0 & 404.9 & 7.5 & 865.5 & 4.1 \\
\hline 2008 & 4414.3 & 24094.1 & -75.6 & -1.7 & 657.1 & 2.7 \\
\hline 2009 & 4699.1 & 29306.7 & 67.3 & 1.4 & 747.0 & 2.5 \\
\hline 2010 & 7226.0 & 44444.0 & 108.5 & 1.5 & 1310.0 & 2.9 \\
\hline 2011 & 8155.0 & 52849.0 & 38.2 & 0.5 & 1054.5 & 2.0 \\
\hline 2012 & 727.0 & 57367.0 & 45.1 & 6.2 & 1090.9 & 1.9 \\
\hline
\end{tabular}

Source: unctadstat.unctad.org (accessed Oct. 17, 2014); www.nbp.pl (accessed Oct. 17, 2014) 
the stock figures for Ukraine as a percentage of total FDI stock abroad are concerned, they usually oscillated around 2 percent, except during the years 2002-2007 when they were higher, even hovering at about 6\% in 2003 and 2004.This trend can be construed to indicate first the growth and then the erosion of Ukraine's role as a destination for Polish FDI, at least in terms of the value of investment. To compare, Poland's FDI stock in the small neighbouring countries of the Czech Republic and Lithuania stood at about USD 2.5 billion in the most recent years. On the other hand, Poland's FDI stock in Ukraine was only slightly lower than that in Russia, where Polish companies had invested over USD 1.1 billion by 2011 (Zimny, 2013).

According to data compiled by the Central Statistical Office of Poland (GUS, 2014), in 2012, 1437 Polish enterprises were holding direct investment abroad, as opposed to 1501 in 2011. These 1437 enterprises were engaged in running 3194 foreign entities in various forms: 2708 had shares in foreign companies, 347 had foreign branches, 106 ran plants, and the remaining 33 were engaged in other forms of foreign participation. Polish parent companies controlled $100 \%$ of shares in 2048 foreign subsidiaries, in 638 units they held a majority stake, and in 508 units their share was less than $50 \%$.

In 2012, Polish parent companies carried out operations in 96 countries. Their subsidiaries, branches and other units were located in almost all the EU countries. The EU countries hosted $61.5 \%$ of all foreign units in which Polish parent companies participated. This was up from $62.3 \%$ in 2011. Similarly to 2011 , about $50 \%$ of all subsidiaries and affiliates were located in seven countries neighbouring Poland. The largest number of units was located in Germany (412), and the second most important host country was Ukraine, hosting 347 subsidiaries and affiliates of Polish parent companies. It should be pointed out that Ukraine was the number one country for hosting Polish companies' foreign units up to 2008 (GUS, 2011). A year later, it was Germany that hosted the largest number of them. Ukraine moved to second position, which it held until 2012. Even the second position of Ukraine according to the number of Polish subsidiaries and affiliates attests to the importance of this country as a destination for Polish FDI, but it is in sharp contrast with the very modest amount of foreign investment value directed to Ukraine from Poland. It can be hypothesized based on these findings that Polish investors in Ukraine are of small size and/or larger companies are reluctant to make a major capital-investment commitment, perhaps due to the largely unfavourable FDI climate and the volatility of the business environment in Ukraine. 
Data from the State Statistics Service of Ukraine (2014) suggest that it is the financial sector together with manufacturing that are leading in the Polish OFDI stock in Ukraine (see Table 3). However, distribution among these two sectors was shifting over time from the manufacturing sector $(56.1 \%$ in 2004 and $24.9 \%$ in 2011) to the financial sector (27.2\% in 2004 and $57.2 \%$ in 2011). Trade and repair services' share was steadily declining, while that of the real estate sector was growing. The share of these two sectors taken together oscillated within the $12.3 \%-16.6 \%$ range. There is also the discernible growing presence of Polish agricultural FDI in Ukraine; in 2004 this industry represented only $0.9 \%$ of total OFDI stock, while in 2011 its share grew to $3.1 \%$.

Table 3

Sectoral Distribution of Poland's Outward FDI Stock in Ukraine as \% of Total (2001-2012)

\begin{tabular}{|c|c|c|c|c|c|c|c|c|c|c|}
\hline & 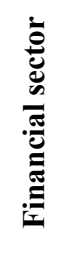 & 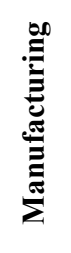 & 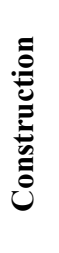 & 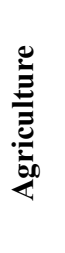 & 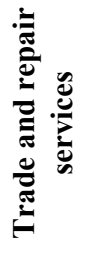 & 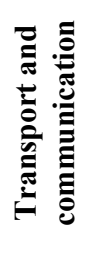 & 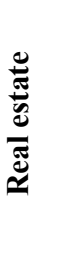 & 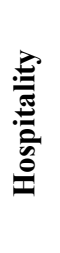 & 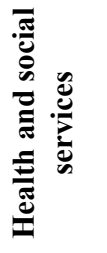 & 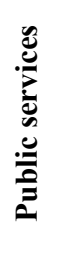 \\
\hline 2001 & 37.1 & 34.6 & 1.9 & 1.1 & 20.7 & 1.1 & 1.6 & 0.0 & 0.0 & 0.0 \\
\hline 2002 & 32.8 & 39.5 & 1.3 & 1.0 & 20.3 & 1.0 & 1.9 & 0.0 & 0.0 & 0.0 \\
\hline 2003 & 35.6 & 41.0 & 0.9 & 1.4 & 15.9 & 1.3 & 3.2 & 0.0 & 0.0 & 0.0 \\
\hline 2004 & 27.2 & 56.1 & 0.9 & 0.9 & 10.6 & 0.9 & 2.1 & 0.4 & - & 0.7 \\
\hline 2005 & 22.9 & 57.4 & 0.8 & 0.8 & 11.1 & 1.1 & 4.6 & 0.4 & 0.1 & 0.6 \\
\hline 2006 & 20.2 & 58.7 & 1.1 & 0.9 & 9.8 & 1.1 & 6.8 & 0.3 & 0.0 & 1.0 \\
\hline 2007 & 39.2 & 43.2 & 1.2 & 0.8 & 7.3 & 0.7 & 7.0 & 0.2 & - & 0.4 \\
\hline 2008 & 51.0 & 30.6 & 1.4 & 4.0 & 6.3 & 1.0 & 5.3 & 0.1 & 0.0 & 0.2 \\
\hline 2009 & 50.4 & 31.0 & 1.1 & 4.7 & 5.6 & 0.9 & 6.1 & 0.1 & 0.0 & 0.2 \\
\hline 2010 & 56.5 & 25.9 & 1.5 & 3.4 & 5.9 & 1.1 & 5.4 & 0.1 & 0.0 & 0.1 \\
\hline 2011 & 57.2 & 24.9 & 1.3 & 3.1 & 4.9 & 1.0 & 7.5 & 0.1 & 0.0 & 0.1 \\
\hline 2012 & 52.0 & 28.2 & 1.9 & 3.6 & 8.0 & 0.8 & 1.4 & - & 0.0 & 1.7 \\
\hline
\end{tabular}

Source: http://www.ukrstat.gov.ua/ (accessed March 25, 2014) 


\section{POLISH FDI IN UKRAINE: FIRM-LEVEL ACTIVITY}

Our analysis of firm-level activity is based on a sample of Polish companies listed on the Warsaw Stock Exchange. Out of 43 companies identified on the Warsaw Stock exchange as having FDI in Ukraine (which is about $10 \%$ of all the companies listed), a sample of 18 companies was selected. This was a judgment sample to secure a good representation of companies across economic sectors and industries, as well as allowing for a broad spectrum of company sizes and different modes of entry into the Ukrainian market.

Initially we attempted to assess the financial position of the Ukrainian subsidiaries of the Polish parent companies under study. Unfortunately, data availability proved to be too limited for such an analysis to be conducted in a meaningful way for at least a majority of the studied companies. Only a handful of them published financial data for their Ukrainian operations (and even these were presented in an inconsistent manner), and our request sent to those that had not published such results was not successful. Therefore, the only performance variable we could analyze with respect to most of the Ukrainian subsidiaries included in the sample is the sales value.

The investment and operational aspects we studied are summarized in Table 4. Table 5, on the other hand, contains sales revenue data which are used to assess the subsidiaries' performance.

The studied companies represented a variety of sectors and industries, including financial intermediation, manufacturing, retail and wholesale trade, construction, real-estate, media, IT, and oil and gas. Most of them had only one subsidiary in Ukraine (only four had more than one subsidiary). Almost all the subsidiaries were established in the 2000s, and most of them in the latter part of the last decade (the date of the establishment for one subsidiary could not be determined). Therefore they are fairly newly established operations and their performance may not have reached full capacity yet.

The vast majority of the studied parent companies hold a $100 \%$ stake in their Ukrainian subsidiaries, all the rest, bar one, hold majority stakes. The only minority stake is held by PGNiG in Dewon; however, even in this case the Polish parent holds the largest percentage of shares among the JV partners.

The Ukrainian assets of the studied companies varied tremendously in 2012. While the two banks, PKO BP and Pekao SA, had assets close to PLN 2 and 3 billion, respectively, several subsidiaries' assets were less than PLN 
Table 4

Summary Characteristics of a Sample of Ukrainian Subsidiaries and Affiliates of Polish Foreign Direct Investors

\begin{tabular}{|c|c|c|c|c|c|c|c|c|}
\hline $\begin{array}{l}\text { Name of parent } \\
\text { company }\end{array}$ & $\begin{array}{l}\text { Sector/ } \\
\text { Industry }\end{array}$ & Name of Ukrainian subsidiary & $\begin{array}{c}\text { Year of } \\
\text { subsidiary } \\
\text { establish. }\end{array}$ & $\begin{array}{c}\% \text { of } \\
\text { stake held } \\
\text { by parent }\end{array}$ & $\begin{array}{l}\text { Ukrainian } \\
\text { assets, 2012 } \\
\text { (PLN'000) }\end{array}$ & $\begin{array}{c}\text { Mode of } \\
\text { entry }\end{array}$ & $\begin{array}{l}\text { Type of } \\
\text { FDI }\end{array}$ & FDI in other countries \\
\hline FOTA JSC & $\begin{array}{l}\text { Wholesale trade/ } \\
\text { automotive }\end{array}$ & FOTA Ukraine LLC & 2006 & $70 \%$ & N/A & $\mathrm{JV}$ & Horizontal & Czech Republic, Hungary, Slovakia \\
\hline PKO BP JSC & Banking & Kredobank JSC & 2004 & $99,6 \%$ & 1866416 & $\mathrm{AQ}$ & Horizontal & No investment \\
\hline Complex JSC & Metals & KomplexmetalUkraina & N/A & $100 \%$ & 3231 & GF & Horizontal & Germany \\
\hline Inter Cars JSC & $\begin{array}{l}\text { Wholesale trade/ } \\
\text { automotive }\end{array}$ & Inter Cars Ukraina LLC & 2000 & $100 \%$ & 36077 & JV & Horizontal & $\begin{array}{l}\text { Czech Republic, Slovakia, Lithuania, Romania, } \\
\text { Croatia, Latvia, Hungary, Italy, Belgium, } \\
\text { Cyprus, Bulgaria, Germany. }\end{array}$ \\
\hline Redan JSC & Retail trade/Clothing & Beta-Reda-Ukraina Ltd. & 2007 & $100 \%$ & 17410 & GF & Horizontal & Russia \\
\hline $\begin{array}{l}\text { Polimex-Mostostal } \\
\text { JSC }\end{array}$ & Construction & $\begin{array}{l}\text { Cherwonogrd ZKM-Ukraina ALC } \\
\text { Polimex-MostostalUkraina SAZ PrSJC }\end{array}$ & $\begin{array}{l}2006 \\
2006\end{array}$ & $\begin{array}{c}99,61 \% \\
100 \%\end{array}$ & $\begin{array}{l}\text { N/A } \\
\text { N/A }\end{array}$ & $\begin{array}{l}\mathrm{AQ} \\
\mathrm{GF}\end{array}$ & $\begin{array}{l}\text { Horizontal } \\
\text { Horizontal } \\
\end{array}$ & Romania, Italy, Germany, Russia, Hungary \\
\hline Echo Investment JSC & Real-estate & Echo Investment Ukraine LLC & 2007 & $100 \%$ & N/A & GF & Horizontal & Hungary, Romania \\
\hline Pekao JSC & Banking & PJSC UniCredit Bank & 1997 & $100 \%$ & 2265490 & $\mathrm{AQ} \& \mathrm{GF}$ & Horizontal & France \\
\hline Comarch JSC & IT & Comarch LLC & 2004 & $100 \%$ & 2314 & GF & Horizontal & $\begin{array}{l}\text { Austria, Germany, UAE, Albania, USA, Panama, } \\
\text { Canada, Russia, United Kingdom, Switzerland, } \\
\text { Luxembourg, Finland, France, Belgium, China. }\end{array}$ \\
\hline Zelmer JSC & Electro-engineering & $\begin{array}{l}\text { Zelmer Ukraine LLC } \\
\text { MBT Trade LLC }\end{array}$ & $\begin{array}{l}2007 \\
2011\end{array}$ & $\begin{array}{l}100 \% \\
100 \%\end{array}$ & N/A & $\begin{array}{l}\text { GF } \\
\text { GF }\end{array}$ & $\begin{array}{l}\text { Horizontal } \\
\text { Horizontal } \\
\end{array}$ & $\begin{array}{l}\text { Czech Republic, Slovakia, Russia, Hungary, } \\
\text { Romania, Bulgaria }\end{array}$ \\
\hline $\begin{array}{l}\text { Quantum Software } \\
\text { JSC }\end{array}$ & IT & Quantum International Ltd. & 2008 & $100 \%$ & N/A & GF & Horizontal & Russia, Spain, Brazil and Chile \\
\hline Mercor JSC & Building materials & MercorUkraina LLC & 2006 & $55 \%$ & N/A & $\mathrm{JV}$ & Horizontal & $\begin{array}{l}\text { Romania, Russia, Spain, Slovakia, Czech } \\
\text { Republic }\end{array}$ \\
\hline Plast-Box JSC & Plastics materials & Plast-Box Ukraina LLC & 2004 & $100 \%$ & 28182 (a) & GF & Horizontal & No investment \\
\hline PZU JSC & Insurance & $\begin{array}{l}\text { PrJSC IC PZU Ukraine Life Insurance } \\
\text { PrJSC IC PZU Ukraine } \\
\text { LLC SOS Services Ukraine }\end{array}$ & $\begin{array}{l}2005 \\
2005 \\
2005\end{array}$ & $\begin{array}{l}100 \% \\
100 \% \\
100 \%\end{array}$ & $\begin{array}{c}86201 \\
156607 \\
701\end{array}$ & $\begin{array}{l}\text { GF } \\
\text { GF } \\
\text { GF }\end{array}$ & $\begin{array}{l}\text { Horizontal } \\
\text { Horizontal } \\
\text { Horizontal }\end{array}$ & Lithuania \\
\hline PGNiG JSC & Oil \& gas & $\begin{array}{l}\text { Poltava Services LLC } \\
\text { Dewon CJSC }\end{array}$ & $\begin{array}{l}2011 \\
2000\end{array}$ & $\begin{array}{c}99 \% \\
36.4 \%\end{array}$ & $\begin{array}{l}\text { N/A } \\
\text { N/A }\end{array}$ & $\begin{array}{l}\text { GF } \\
\text { JV }\end{array}$ & $\begin{array}{l}\text { Horizontal } \\
\text { Vertical }\end{array}$ & $\begin{array}{l}\text { Norway, Oman, Netherlands, Germany, } \\
\text { Sweden, Libya, plus exploration concessions in } \\
\text { Pakistan, Denmark and Egypt, and branch offices } \\
\text { in many other countries on several continents }\end{array}$ \\
\hline Agora JSC & Media & Agora Ukraine LLC & 2007 & $100 \%$ & 516 & GF & Horizontal & No investment \\
\hline Aplisens JSC & Electro-engineering & $\begin{array}{l}\text { GT APLISENS-TER Ukraina LLC } \\
\text { TOV-APLISENS Ukraina LLC }\end{array}$ & $\begin{array}{l}2005 \\
2006\end{array}$ & $\begin{array}{c}51 \% \\
100 \%\end{array}$ & $\begin{array}{r}550 \\
\mathrm{~N} / \mathrm{A}\end{array}$ & $\begin{array}{l}\text { JV } \\
\mathrm{GF}\end{array}$ & Vertical & $\begin{array}{l}\text { Czech Republic, France, Russia, Germany, } \\
\text { Belarus }\end{array}$ \\
\hline FFiLŚnieżka JSC & Paints and varnishes & \begin{tabular}{|l} 
Śnieżka-Ukraina LLC \\
Śnieżka LLCVistova \\
\end{tabular} & $\begin{array}{l}1999 \\
2005\end{array}$ & $\begin{array}{c}82.52 \% \\
100 \% \\
\end{array}$ & 20496 (b) & $\begin{array}{l}\mathrm{JV} \\
\mathrm{GF}\end{array}$ & $\begin{array}{l}\text { Horizontal } \\
\text { Horizontal } \\
\end{array}$ & Belarus, Moldova, Russia and Romania \\
\hline
\end{tabular}

Source: Compiled by the authors based on the most recently available (as of May, 2014) Annual Reports of the companies concerned Note: $\mathrm{GF}=$ greenfield investment; $\mathrm{AQ}=$ acquisition; $\mathrm{JV}=$ joint venture

(a) Data for 2011

(b): Assets of both the subsidiaries in Ukraine 
Table 5

Gross sales revenues of selected Ukrainian subsidiaries of Polish parent companies, 2008-2012 (PLN'000)

\begin{tabular}{|c|c|c|c|c|c|c|c|c|c|}
\hline $\begin{array}{c}\text { Name } \\
\text { of subsidiary }\end{array}$ & 2008 & 2009 & $\begin{array}{c}\% \\
\text { change } \\
\text { YoY }\end{array}$ & 2010 & $\begin{array}{c}\% \\
\text { change } \\
\text { YoY }\end{array}$ & 2011 & $\begin{array}{c}\% \\
\text { change } \\
\text { YoY }\end{array}$ & 2012 & $\begin{array}{c}\% \\
\text { change } \\
\text { YoY }\end{array}$ \\
\hline $\begin{array}{l}\text { Komplexmetal- } \\
\text { Ukraina }\end{array}$ & 2348 & 2261 & $-3.71 \%$ & 3584 & $58.51 \%$ & 34 & $46.04 \%$ & 5372 & $2,64 \%$ \\
\hline Inter Cars Ukraina & 68827 & 71816 & $4.34 \%$ & 90 & & & $-6.96 \%$ & 115 & $34,98 \%$ \\
\hline Beta-R & 5695 & 6512 & $14.35 \%$ & 9091 & 39. & 19256 & $111.81 \%$ & 29318 & $52,25 \%$ \\
\hline Comarch & 3572 & 2363 & $-33.85 \%$ & 2621 & $10.92 \%$ & 4611 & $75.93 \%$ & 4507 & $-2,26 \%$ \\
\hline Agora Ukraine & 5 & 369 & $7280.00 \%$ & 251 & $-32.98 \%$ & 70 & $-72.11 \%$ & 33 & $-52,86 \%$ \\
\hline Plast-Box Ukrai & 12734 & 14155 & $11.16 \%$ & 21574 & $52.41 \%$ & 412 & $36.33 \%$ & 39278 & $33,54 \%$ \\
\hline $\begin{array}{l}\text { GT APLISENS-TER } \\
\text { Ukraina } \\
\end{array}$ & 767 & 1565 & $\%$ & 2189 & $7 \%$ & 76 & $8.54 \%$ & 184 & $-8,08 \%$ \\
\hline PJSC UniCredit & & 405793 & (2.) & 335766 & $-17.26 \%$ & & $-17.80 \%$ & 241614 & $-12.46 \%$ \\
\hline ZU Ukr: & $-5+2+$ & 80785 & - & 106469 & $31.80 \%$ & 121022 & $13.67 \%$ & 142228 & $17.52 \%$ \\
\hline Mercor-Ul & 11872 & 6225 & $-47.57 \%$ & 5344 & $-14.15 \%$ & 8518 & $59.39 \%$ & 10493 & $23,19 \%$ \\
\hline OTA-Ukraine (a) & 21678 & 21354 & $-1.49 \%$ & 27499 & $28.78 \%$ & 30062 & $9.32 \%$ & 30082 & $0,07 \%$ \\
\hline Śnieżka-Ukraine (a) & 110077 & 101028 & $-8.22 \%$ & 105575 & $4.50 \%$ & 118476 & $12.22 \%$ & 132024 & $11.44 \%$ \\
\hline
\end{tabular}

Source: Compiled by the authors based on Annual reports of the companies concerned

Note: Since 2010, Mercor's financial year has run from 1 April to 31 March, with the exception that the first year after the change lasted for 15 months, i.e. from 1 January 2010 to 31 March 2011.

(a) The so-called "segment revenues", i.e. the combined revenues of all the units run by the Polish parent in Ukraine.

1 million. Of the non-financial companies, the biggest asses (over PLN 28 million) were held by Plast-Box, a company making plastic materials. Presumably, the Ukrainian assets of several other companies are also sizeable, but the appropriate data are missing.

Regarding the FDI entry modes, all the three modes - greenfield, acquisition, and joint venture - were used. However, greenfield investments predominate among the studied parent companies. Of the 18 companies, eleven used the greenfield mode exclusively, and four used both a greenfield and acquisition or greenfield and JV for the establishment of their two subsidiaries. The use of two different modes of entry by one investor is noteworthy. The predominance of wholly-owned subsidiaries established through the greenfield mode can be explained by the high investment risk (Brouthers and Brouthers, 2001). The small cultural and psychological distance between Poland and Ukraine, as noted before, would also point to the greenfield mode, as some studies find high cultural distance to be linked 
to a preference for joint ventures (see e.g. Kogut and Singh, 1988). The reports of Ukrainian courts taking Ukrainian sides in ownership disputes involving foreign investors, referred to in one of the preceding sections, is yet another argument for avoiding JVs as a mode of entry into the Ukrainian market.

The vast majority of Polish investors under study pursue the horizontal type of FDI. This means that they duplicate certain value chain activities between Poland and Ukraine, typically distributing and selling products that they also market in Poland. However, in some cases the product assortment sold in Ukraine is narrower than the one offered in the domestic market, or different product lines are emphasized in Ukraine than in Poland. For example, Agora's subsidiary focuses more on Internet news production and distribution in Ukraine, while in Poland the company's main business is hard copy newspaper distribution. Likewise, PZU Ukraine focuses on property insurance, whereas in Poland it offers a full range of insurance products. The predominance of horizontal investment points to the market-seeking motives of Polish investors. The almost total lack of inferred efficiency-seeking motives is surprising, given the location advantages of Ukraine discussed before (notably, a relatively inexpensive and well-educated workforce), but confirmed by some other studies (e.g. Kudina and Jakubiak, 2008). One could argue that this situation is unfortunate for both Ukraine and foreign investors. For Ukraine it means weak FDI spillovers and the problematic contribution of foreign investors to productivity growth, employment and industrial upgrading. For investors, it means missing out on the potential to rationalize value-chain configurations and increase their operational efficiency through investment in Ukraine.

One of the two companies that are engaged in vertical FDI in Ukraine is the energy giant, PGNiG. Its Ukrainian subsidiary, Poltava Services LLC, is involved in oil and gas exploration (geophysical and geological surveys and drilling wells) and is a subsidiary of GK PNiG Kraków (a Polish subsidiary of PGNiG). While Poltava represents rather a horizontal FDI (basically, it provides the same exploration services as its Kraków-based parent), Dewon CSJC was set up to extract natural gas from the Sachalin field in Eastern Ukraine for the Polish market, and therefore can be categorized as vertical FDI. Dewon is also a rare case of resource-seeking FDI motives among the studied companies.

For most of the studied companies, Ukraine is not the only foreign market where they have invested. Some of them, like Inter Cars, Comarch and PGiNG, have operations in multiple foreign markets. For three companies 
(PKO BP, Plast-Box and Agora), however, Ukraine is the only country of foreign investment. A concentration on the Central and East European markets is another feature of the geographic scope of the internationalization via FDI of the companies under study; more than half of the companies have their subsidiaries located exclusively or predominantly in this region.

Table 5 provides information on the sales revenues of a subsample (for which such data were available) of the investigated Ukrainian subsidiaries, for a five-year period (2008-2012). Generally, wild year-to-year fluctuations and great differences between the subsidiaries can be observed in those sales revenues. Only two of the subsidiaries included in the table experienced strong and consistent growth in sales, namely: Beta-Reda-Ukraina (over $400 \%$ growth between 2008 and 2012), and Plast-Box (over200\%). Since Beta-Reda-Ukraina was established in 2007, this can be considered a spectacular sales performance. Of course, part of this growth was eroded by inflation. Nevertheless, the two subsidiaries were performing very well, as far as sales are concerned. Since for Plast-Box, Ukraine is the only FDI host country, it makes this company's sales performance even more admirable. Other subsidiaries were experiencing sales declines in one, two or three years of the four-year period, for which the percentage increases were calculated, and one company (Mercor) had lower sales in 2012 than in 2008. GT APLISENS-TER experienced strong growth until 2012, when its sales declined. Nevertheless, the company had sales $185 \%$ higher in 2012 compared to 2008. An interesting case is provided by Agora. After it was established in 2007, it experienced a jump in sales between 2008 and 2009 (by over $700 \%$ ), but in the subsequent years the sales declined sharply. In conclusion, the sales dynamics of the nine companies for which sales data were available represents a whole spectrum of performance, from spectacular to very poor.

\section{CONCLUSIONS}

Relatively little research has so far been conducted on FDI in Ukraine, and hardly any on Polish FDI in Ukraine. As both Poland's outward FDI and Ukraine's inward FDI are expanding, the importance of this research area should not be questioned. It is important to provide new findings that can contribute to the development of FDI theory in the context of transition and emerging economies, and it is equally important to provide investing companies and policy makers with generalized insights and conclusions relating to the challenges, opportunities, and successful strategies for investing in Ukraine. 
As this paper clearly demonstrates, Ukraine represents a challenging FDI environment for foreign companies. In spite of the country's location advantages that relate to its market size, market growth, competitive structure, and the availability of a well-educated and inexpensive labour force and natural resources, the institutional environment of business in general and FDI climate in particular represent major location disadvantages. As a result, FDI inflows to Ukraine were for many years far below the country's potential to attract FDI. However, from 2003 onwards, in most of the remaining years of the studied period, Ukraine was catching up to Poland, in relative terms, when it comes to attracting FDI. Poland did not take note of this trend though. In spite of the geographic and cultural proximity, and the special political relations between the two countries, the level of Polish investment in Ukraine remains very modest; currently, Polish FDI flows to Ukraine and stock in Ukraine represent only 1-2\% of the value of outward FDI from Poland. At the same time, however, the second largest number of investors who established their subsidiaries and affiliates in Ukraine were Polish. Only Germany hosts more Polish subsidiaries than Ukraine. Clearly, there is a discrepancy between the value of Polish FDI in Ukraine and the level of interest and activity among Polish investors there. This discrepancy seems to deserve further investigation and explanation.

Our study of a sample of Polish direct investors in Ukraine indicates that their subsidiaries' assets are relatively small (except the financial services companies, which however represent a special case); most of them were established as wholly-owned subsidiaries through greenfield investment; are predominantly involved in horizontal FDI, implying market-seeking motives; and for the vast majority of the investing companies Ukraine is not the only country where they had invested, but is typically part of a CEE cluster of investment destinations. Through our analysis of sales dynamics of a sub-sample of subsidiaries we found sales outcomes to be very uneven across the firms, ranging from spectacular to very poor sales performance.

\section{Policy and Managerial Implications}

Ukraine is an excellent example of the importance of institutional quality in attracting FDI. The country's low position in several rankings presented in this paper that assess, among other things, institutional quality attest to this importance. Therefore the main policy recommendation for Ukraine in the area of FDI should be to substantially improve institutional infrastructure. 
In line with the ideas presented by Acemoglu and Robinson (2012), the main problem in Ukraine was the lack of change of the political arrangements that would allow for building and maintaining inclusive institutions. Instead, the economic regime in Ukraine allowed for the creation of extractive institutions - where the accumulation of power and prosperity is distributed among a relatively narrow group of individuals. Inclusive institutions, on the other hand, allow for the distribution of accumulated power in a democratic way, in consequence leading to economic liberalization.

An improvement of institutional quality in Ukraine would increase FDI flows and inclusive institutions would allow for sustainable growth and macroeconomic stabilization. The strengthening of the market institutions and the elimination, or at least the significant reduction, of corruption could have a positive impact on Ukraine's attractiveness as an FDI destination. Also, Ukraine might benefit from a transparent privatization and reforms targeted to decentralize public administration. There is also a need for good limited liability company law and improvements in public procurement law; these reforms however have to be transparent and done with great care to include mechanisms allowing for constant improvement and incisiveness. Previous economic regimes had a tendency to produce policy packages that later were not properly executed, for instance the presidential concept "on the way to honesty", that was never implemented because of the insufficient development of institutions to carry it out.

The policy packages to attract FDI introduced in Ukraine in 2012, which included five main components (Invest PROPOSAL, Invest INFRASTUCTURE, Invest PARTNERSHIP, Invest MARKETIN, Invest CLIMATE), were designed to create mechanisms conducive to foreign investment. They seemed to go in the right direction. Because of the short time of their existence, the effectiveness of these packages could not be assessed, although anecdotal information points to the lack of straightforward rules which allows for corruption to take place (Cywiński and Harasym, 2014).

Polish companies investing in Ukraine can be assisted within the institutional help towards Polish outward FDI, which is now one of the main priorities of Polish Foreign Policy for 2012-2016. Of particular importance is the Ministry of Economy's (ME) promotional campaign "Made in Poland" outlining the main directions of Poland's strategy to support outward FDI. The ME's support for Polish outward investment is not only limited to promotional activities. An important element of institutional support for 
Polish overseas investment is provided by diplomatic missions, whose activities are coordinated by the ME's Department in charge of promotion and bilateral cooperation. Poland could also act more decisively within the provisions of the Agreement between the Government of the Republic of Poland and the Government of the Republic of Ukraine for the Reciprocal Promotion and Protection of Investments to help avoid the bureaucratic and judicial fairness problems so often encountered by Polish firms operating in Ukraine.

Finally, we can draw some implications of our study for Polish companies investing or planning to invest in Ukraine. As this article made clear, conditions for doing business in Ukraine remain very difficult for Polish investors. The Ukrainian state very often does not live up to its obligations vis-à-vis enterprises, including those with foreign capital. Some of the biggest barriers to doing business in Ukraine identified in this article are corruption, non-transparent, incoherent and constantly evolving regulations, particularly tax regimes, that create uncertainty and risk for investors, and time-consuming and costly approval procedures. However, in spite of these difficult conditions, at the end of 2013, there were 800 companies with Polish capital registered in Ukraine. Given the location advantages identified in this study, Polish enterprises should not shy away from Ukraine as a place for investment. Particular areas of opportunity include: airport infrastructure, advanced engineering (airspace and energy), financial services, agriculture, fast-moving consumer goods, and healthcare.

Ukraine is associated with a high risk in running a business, which in turn is often compensated by a high return on invested capital. Cooperation between foreign investors and local firms often runs into problems, therefore Polish companies prefer to set up greenfield investments. Ukraine allows foreigners to purchase businesses and property (with the exception of arable land), to repatriate revenue and profits, and to receive compensation if their property is nationalized. This is conducive to the greenfield mode of FDI as opposed to joint ventures. At the same time, the analysis of the sample of Polish investors in Ukraine indicated that they engage predominantly in horizontal FDI, seeking market opportunities. Meanwhile, due to Ukraine's advantage vis-à-vis Poland in costs of labour and other inputs, as well as the existence of a large industrial base and skilled workforce, vertical FDI, allowing for value-chain rationalization and thus efficiency seeking, seems an unutilized type of Polish investment in Ukraine. Simply put, Polish companies should locate in Ukraine those business activities that can be performed there more efficiently than in Poland. 


\section{Further Research}

As this paper represents the first stage of a multi-stage study of Polish FDI in Ukraine and is exploratory in nature, further research is envisioned. In the next stage, we plan to conduct interviews in eight to ten companies drawn from the current sample in order to derive information that is not available in published sources, particularly on investors experience in Ukraine and their perception of its location advantages and disadvantages. We intend to apply within-case and cross-case qualitative analyses of the information collected through in-depth interviews. The second stage should allow for formulating appropriate hypothesis to be tested through quantitative research based on a survey of all Polish companies that have invested in Ukraine, which is planned for the third stage of this research project.

\section{REFERENCES}

Acemoglu, D., Robinson, J. A., Why Nations Fail. Random House Inc., New York, 2012.

Bevan, A. A., Estrin, S, The Determinants of Foreign Direct Investment into European Transition Economies, "Journal of Comparative Economics", 32, pp. 775-787, 2004.

Bloningen, B., A Review of the Empirical Literature on FDI Determinants, "Atlantic Economic Journal”, 33, pp. 383-403, 2005.

Bonikowska, M., Rabiej, P., Żurek, K., Badanie THINKTANK: Jak państwo wspiera ekspansje firm? [THINKTANK Research: How Poland Supports Expanding Firms], "THINKTANK", Autumn 2012. Paper presented at the conference organized by the Polish Ministry of Economy of The Republic of Poland, Warsaw, 6 December 2012.

Brouthers, K. D., Brouthers, L. E., Explaining the National Cultural Paradox, "Journal of International Business Studies", 32(1), pp. 177-189, 2001.

Brouthers, L. E., Mukhopadhyay, S., Wilkinson, T. K., Brouthers, K. D., International Market Selection and Subsidiary Performance: A Neural Network Approach, "Journal of World Business", 44, pp. 262-273, 2009.

Buckley, P. J., Clegg, J., Cross, A. R., Liu, X., Voss, H., Zheng, P., Determinants of Chinese FDI, "Journal of International Business Studies", 38(4), pp. 499-518, 2007.

Burant, S. R., International Relations in a Regional Context: Poland and Its Eastern Neighbours. Lithuania, Belarus, Ukraine, "Europe-Asia Studies", 45(3), pp. 395-418, 1993.

Busse, M., Hefeker, C., Political Risk, Institutions and Foreign Direct Investment, "European Journal of Political Economy”, 23(2), pp. 397-416, 2007.

Chapman, M., Gajewska-De Mattos, Cleg, J., Buckley P., Close Neighbours and Distant Friends - Perceptions of Cultural Distance, "International Business Review", 17, pp. 217-234, 2008. 
Crane, K., Larrabee, F. S., Encouraging Trade and Foreign Direct Investment in Ukraine, RAND National Security Research Division paper prepared for Institute of European and International Studies in Kyiv. RAND Corporation, 2007.

Cywiński, Ł., Harasym, R., Economic Regime and Foreign Direct Investment, "e-Finance", 10(2), pp. 11-20, 2014.

Dunning, J. H., The Eclectic Paradigm of International Production: A Restatement and Some Possible Extensions, "Journal of International Business Studies", 19 (1), pp.1-31, 1988.

Dunning, J. H., Multinational Enterprises and the Global Corporation. Addison-Wesley, New York, 1993.

Dunning, J. H., The Eclectic (OLI) Paradigm of International Production: Past, Present and Future, "International Journal of the Economics of Business", 8(2), pp. 173-190, 2001.

Dunning, J. H., Institutional Reform, Foreign Direct Investment and European Transition Economies [in:] R.E. Grosse, E. R. (ed.), International Business and Government Relations in the $21^{\text {st }}$ Century, pp. 49-78. Cambridge University Press, Cambridge, 2005.

Dunning, J. H., Lundan, S. M, Institutions and the OLI Paradigm of the Multinational Enterprise, "Asia Pacific Journal of Management”, 25, pp. 573-593, 2008.

Embassy of the Republic of Poland in Kiev (2013) Bariery w dostępie do rynku ukraińskiego [Barriers in Access to the Ukrainian Market]. Trade and Investment Promotion Department, http://kiev.trade.gov.pl/pl/ukraine/article/detail,421,Bariery_w_dostepie_do_ rynku_ukrainskiego.html (accessed 13.03.2013).

Ernst \& Young. (2011). Organization as Author. Ukraine FDI report 2011.

Faeth, I., Determinants of Foreign Direct Investment - A Tale of Nine Theoretical Models, "Journal of Economic Surveys", 23(1), pp. 165-196., 2009.

Gorzelak, G., Tucholska, A. (eds), Historyczno-kulturowe uwarunkowania rozwoju: Polska $i$ Ukraina [Historical and Cultural Determinants of Development: Poland and Ukraine]. Wydawnictwo Naukowe Scholar, Warszawa, 2008.

GUS, Działalność podmiotów posiadających udziały $w$ podmiotach z siedziba za granica [Activities of Polish Firms Owning Shares in Operations Abroad]. Główny Urząd Statystyczny [Central Statistical Office] (GUS), Warsaw, 2011.

GUS., Działalność podmiotów posiadających udziały w podmiotach z siedziba za granica [Activities of Polish Firms Owning Shares in Operations Abroad]. Główny Urząd Statystyczny [Central Statistical Office] (GUS), Warsaw 2014.

The Heritage Foundation, Index of Economic Freedom, Washington, DC, http://www.heritage.org/index/ranking (accessed 13.03.2013)

Herzfeld, T., Weiss, C., Corruption and Legal Ineffectiveness: An Empirical Analysis, "European Journal of Political Economy", 19, pp. 21-632, 2003.

Iglicka, K., Gmaj, K., Circular Migration Patterns. Migration between Ukraine and Poland, "European University Institute", Florence, 2010.

Institute for Economic Research and Policy Consulting in Ukraine (2007), The Structure of Foreign Direct Investment in Ukraine and its Macroeconomic Implications. German Advisory Group on Economic Reform. .

Johanson, J., Vahlne, J. E., The Internationalization Process of the Firm - A Model of Knowledge Development and Increasing Foreign Market Commitments, "Journal of International Business Studies”, 8, 1, pp. 23-32, 1977. 
Karaszewski, W., Jaworek, M., Kuzel, M., Szałucka, M., Szustek, A., Długołęcka, K., Aktywność inwestycyjna polskich przedsiębiorstw za granica $w$ postaci inwestycji zagranicznych [Investment Activity of Polish Companies Abroad as Foreign Investment]. Nicolaus Copernicus University in Torun, 2010.

Kogut, B., Singh, H., The Effects of National Culture on the Choice of Entry Mode, "Journal of International Business Studies", Fall, pp. 441-432, 1998.

Kononov, O., Ukraine's Inward FDI and its Policy Context. Columbia FDI Profiles. Vale Columbia Center on Sustainable International Investment, April, 2010.

Kudina, A., Jakubiak, M., The Motives and Impediments to FDI in the CIS, "Proceedings of the VII Global Forum on International Investment”, OECD, 27-28 March, 2008.

Ljidsman, R. W., Can Ukraine Compete for Resource based Foreign Direct Investment? Retrieved 17.12.2012 from U.S.-Ukraine Web site: http://www.usukraine.org/bizlinks/ Reports/Ukraine-OPED-paper.pdf.

Loree, D. W., Guisinger, S. E., Policy and Non-policy Determinants of U.S. Equity Foreign Investment, "Journal of International Business Studies", 26(2), pp. 281-299, 1995.

Lutz, S. H., Talavera, O., Do Ukrainian Firms Benefit from FDI? Discussion Paper No. 0305. Centre for European Economic Research, Mannheim, Germany, 2003.

Mac, A., Foreign Direct Investment Drives Growth in Ukraine. "Magisters Insight", October, 2008 .

Shenkar, O., Cultural Distance revisited. Towards a More Rigorous Conceptualization and Measurement of Cultural Differences, "Journal of International Business Studies", 32(3), pp. 519-535, 2001.

State Statistics Service of Ukraine, FDI in Ukraine, http://www.ukrstat.gov.ua/ (accessed 25.03.2014).

Tansil, O. V., Eff, E. A., (2011). Foreign Direct Investment in Ukraine: Why So Little? Retrieved 17.12.2012 from Middle Tennessee State University: http://capone.mtsu.edu/eaeff/downloads/Ukraine\%20FDI.pdf.

Tytell, I., Yudaeva, K., The role of FDI in Eastern Europe and New Independent States: New Channels for Spillover Effect, "Center for Economic and Financial Research Working Paper" No. 0060, 2005.

Transparency International (2013). Corruption Perception Index 2004-2013, Berlin, Germany, http://www.transparency.org/cpi2013/results (accessed 17.10.2014).

UNCTAD, World Investment Prospects Survey 2009-11. United Nations Conference on Trade and Development, New York and Geneva, 2009.

World Bank, Doing Business 2013. Smarter Regulations for Small and Medium-Size Enterprises, Washington, DC, http://www.doingbusiness.org/rankings (accessed 13.03.2013).

World Economic Forum (2007-2012). Global Competitiveness Index, Geneva, Switzerland, $\mathrm{http} / / / w w w . w e f o r u m . o r g /$ issues/global-competitiveness (accessed 13.03.2013)

Zimny, Z., Outward FDI from Poland and its policy context, 2012. Columbia FDI Profiles. Retrieved 21.01.2013 from Vale Columbia Center on Sustainable International Investment Web site: http://www.vcc.columbia.edu/files/vale/documents/Poland_OFDI__14_Jan_2013_-_FINAL_0.pdf.

Received: May 2013, revised: November 2014 


\begin{tabular}{|c|c|c|c|c|c|c|}
\hline Year & $\begin{array}{c}\text { GDP } \\
\text { of Ukraine } \\
\text { (USD m) }\end{array}$ & $\begin{array}{c}\text { GDP } \\
\text { of Poland } \\
\text { (USD m) }\end{array}$ & $\begin{array}{c}\text { FDI, net inflows } \\
\text { (USD m) into } \\
\text { Ukraine }\end{array}$ & $\begin{array}{l}\text { FDI inflows } \\
\text { (USD m) } \\
\text { into Poland }\end{array}$ & $\begin{array}{c}\text { Ratio of Ukraine's } \\
\text { GDP to Poland's } \\
\text { GDP }\end{array}$ & $\begin{array}{l}\text { Ratio of Ukraine's FDI } \\
\text { inflows to Poland's FDI } \\
\text { inflows }\end{array}$ \\
\hline 1992 & 73942 & 92295 & 200 & 678 & 0.80 & 0.29 \\
\hline 1993 & 65649 & 93964 & 200 & 1715 & 0.70 & 0.12 \\
\hline 1994 & 52550 & 108405 & 159 & 1875 & 0.48 & 0.08 \\
\hline 1995 & 48214 & 139062 & 267 & 3659 & 0.35 & 0.07 \\
\hline 1996 & 44558 & 156684 & 521 & 4498 & 0.28 & 0.12 \\
\hline 1997 & 50150 & 157154 & 623 & 4908 & 0.32 & 0.13 \\
\hline 1998 & 41883 & 172902 & 743 & 6365 & 0.24 & 0.12 \\
\hline 1999 & 31581 & 167802 & 496 & 7270 & 0.19 & 0.07 \\
\hline 2000 & 31262 & 171276 & 595 & 9343 & 0.18 & 0.06 \\
\hline 2001 & 38009 & 190421 & 792 & 5714 & 0.20 & 0.14 \\
\hline 2002 & 42393 & 198179 & 693 & 4131 & 0.21 & 0.17 \\
\hline 2003 & 50133 & 216801 & 1424 & 4589 & 0.23 & 0.31 \\
\hline 2004 & 64883 & 252769 & 1715 & 12716 & 0.26 & 0.13 \\
\hline 2005 & 86142 & 303912 & 7808 & 11051 & 0.28 & 0.71 \\
\hline 2006 & 107753 & 341670 & 5604 & 21518 & 0.31 & 0.26 \\
\hline 2007 & 142719 & 425322 & 10193 & 25573 & 0.33 & 0.40 \\
\hline 2008 & 179992 & 529401 & 10700 & 15031 & 0.34 & 0.71 \\
\hline 2009 & 117228 & 430917 & 4769 & 14388 & 0.27 & 0.33 \\
\hline 2010 & 136422 & 469799 & 6451 & 17074 & 0.29 & 0.38 \\
\hline 2011 & 163422 & 515771 & 7207 & 17357 & 0.32 & 0.41 \\
\hline 2012 & 176603 & 490212 & 7833 & 6701 & 0.36 & 1.17 \\
\hline
\end{tabular}

